JANET HARTIN, UC Cooperative Extension Environmental Horticulture Advisor, San Bernardino and Los Angeles Counties; PAM GEISEL, Director Emeritus, UC Statewide Master Gardener Program, UC Cooperative Extension Horticulture Advisor Emeritus, Fresno County, and County Director, Glenn County; ALI HARIVANDI, UC Cooperative Extension Environmental Horticulturalist Emeritus; and RACHEL ELKINS, UC Cooperative Extension Pomology Farm Advisor, Lake and Mendocino Counties

\title{
Sustainable Landscaping in California
}

\author{
How to Conserve Resources and Beautify Your Home Landscape
}

W hile being a good steward of our environment has been a goal of home landscapers for many years, there is increasing emphasis on adopting sustainable landscaping practices and principles. What exactly is sustainable landscaping? In a nutshell, it involves selecting plants that are adapted to your climate and microclimate and implementing maintenance practices that reduce water waste, protect water quality, nurture soil, recycle organic matter, incorporate integrated pest management (IPM), protect and encourage desirable wildlife, and conserve energy.

Benefits of sustainable landscaping include

- healthy, low-maintenance landscapes

- lower water bills (for those on metered water)

- less water quality degradation

- increased energy conservation due to less pumping and water treatment

- extended life of water resources infrastructure (pumping, water treatment facilities, etc.)

- enhanced wildlife habitat and wildlife corridors

- reduced air pollution

- reduced home cooling and heating costs through strategic plant placement Following the specific recommendations discussed in this publication will help guide you through the process of developing your own beautiful, low-maintenance sustainable landscape.

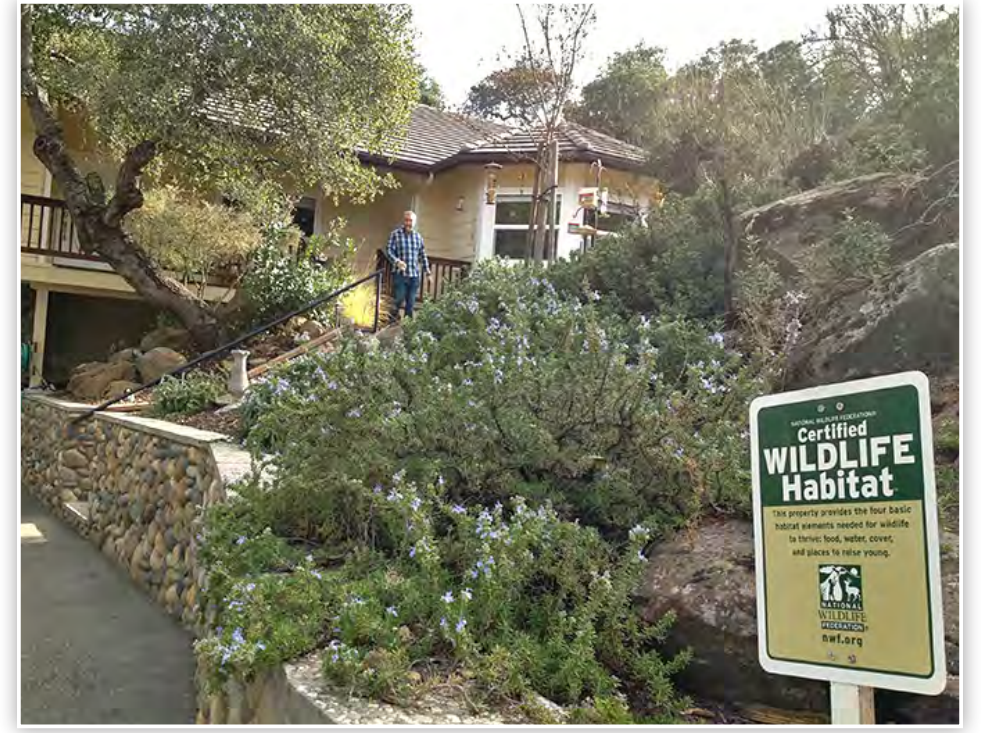

This drip-irrigated home landscape on a slope demonstrates both water-efficient and wildlife-friendly best management practices. Photo: J. Hartin. 


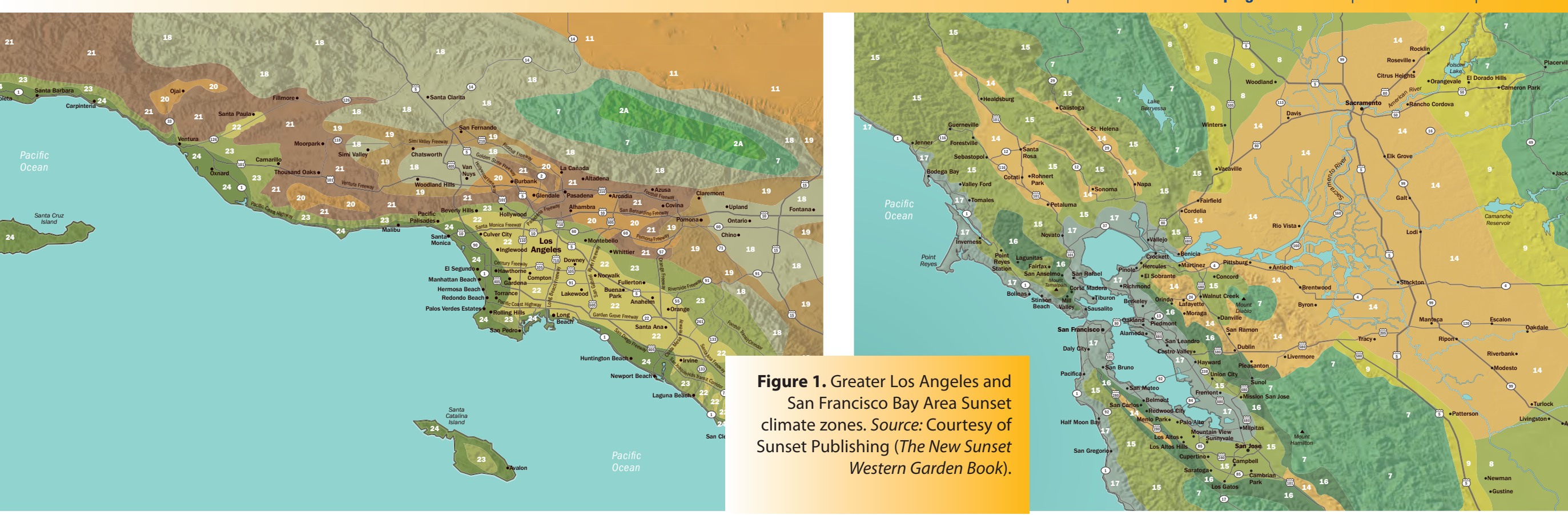

\section{Choose Plants Recommended for Your Climate and MicrocLIMATE}

Choosing landscape plants that perform well in your climate and microclimate is the single most important way to prevent plant decline and loss. Making the right selections can save water, time, and other resources in the long run.

Select plants that are suggested for your specific Sunset climate zone (fig. 1). Sunset zones encompass smaller, more distinct climatic areas than U.S. Department of Agriculture (USDA) plant hardiness zones, which are referenced on plant tags and in many gardening publications. For instance, some plants that perform well in Glendale, California (Sunset zone 20) require greater heat adaptation than plants recommended for Santa Monica, California, a city only 25 miles away in Sunset zone 24. Within San Diego County alone, there are four distinct Sunset zones taking into account coastal, inland, foothill, and desert climates. Even weather in the San Francisco Bay Area varies and includes multiple Sunset zones. To locate your zone, consult The New Sunset Western Garden Book (Brenzel, ed. 2012) or visit the Sunset Climate Zone website, http://www.sunset.com/garden/climate-zones.
Once you have chosen plants suitable for your Sunset zone, narrow down your choices based on which plants on your list will grow well in your microclimate. Microclimates are smaller areas within a climate zone that have unique weather patterns, which can greatly influence plant performance. Examples are shady or windy areas, compacted soils with poor drainage, hot spots adjacent to dark asphalt that reradiate heat, and areas adjacent to current or future construction. Ignoring microclimate effects is a common mistake and a major cause of plant decline. For assistance choosing specific plants that are suitable for your climate and microclimate, you have various options. You can consult a reputable online resource such as the Sunset Plant Finder website, http:// plantfinder.sunset.com, which allows multiple criteria to be entered during a plant search, or the updated Water Use Classification of Landscape Species (WUCOLS) database, http://ucanr.edu/sites/ wucols. You can also consult a reputable nursery or contact a University of California Master Gardener volunteer serving your county (see the California Master Gardener Program website, http://camastergardeners.ucanr.edu/California_Counties_MG_ Websites). 


\section{Avoid invasive plants}

Avoid choosing species known for their invasive potential (fig. 2). These plants have qualities that make them difficult to control. This can result in their escape into wild areas, where they can outcompete populations of native species. Once introduced, invasive plants survive and spread on their own without human assistance. This can result in substantial changes to the character, condition, form, and nature of the invaded habitat. Examples of plants that should be avoided are Scotch broom (Cytisus scoparius) and pampas grass (Cortaderia selloana). For further information on invasive plants to avoid and attractive alternatives with similar aesthetic characteristics, download the free brochures Plant Right (from the PlantRight website, www.plantright.org) or Don't Plant a Pest! (from the Cal-IPC website, www.cal-ipc.org).

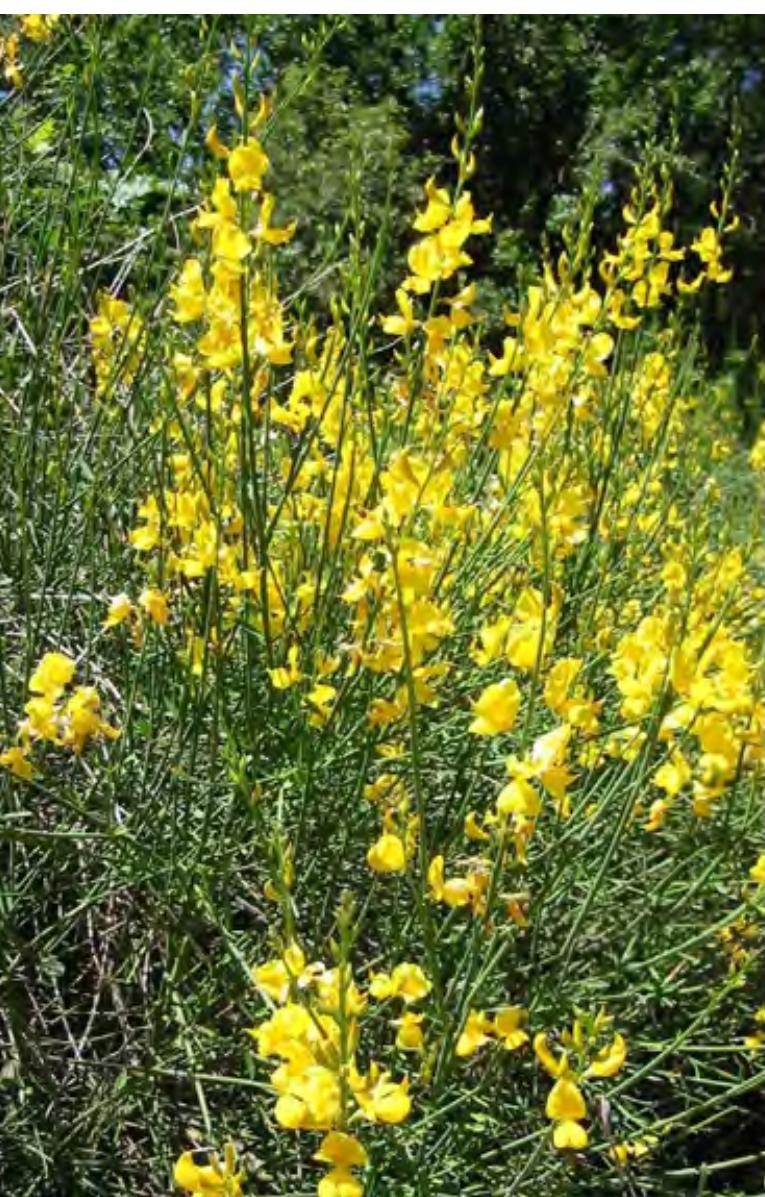

\section{Design and Implement a Water-} EFFICIENT LANDSCAPE

Californians are more interested than ever in beautiful, water-efficient landscapes that conserve an important natural resource and save time and money (fig. 3). About onethird to one-half of water used by a typical California family is directed at outdoor irrigation, averaging about 200 gallons a day. (For converting U.S. customary units to metric units, see the table at the end of this publication.) Significant savings can be realized through selecting water-efficient plants and ensuring efficient irrigation.

Many homeowners hear the terms xeriscaping or xeriphytic landscape and wonder how they relate to water-efficient landscaping. The word xeriscape is derived from the Greek word xeros, meaning dry, and the English word landscape. Information in

Figure 2. Scotch broom (Cytisus scoparius) is an example of an invasive plant that should be avoided. Photo: Courtesy of J. S. Peterson @ USDA-NRCS Plants Database. this publication represents best management practices appropriate for California landscapes; it includes and expands on xeriscape practices that are well known and relevant.

The good news is that, in most instances, you do not need to completely overhaul your entire landscape or commit to expensive fixes to save water. While native gardens are generally water efficient and low maintenance, there are many non-native plants that thrive in California and are just as drought efficient. Adding diversity to your plant palette is always a good idea because it can result in fewer pest problems and a more interesting, aesthetically appealing landscape. Most of the water wasted in residential landscapes is not due to thirsty plants; it is the result of inefficient and ineffective watering practices. Following the recommendations below will save you money, water, and time.

\section{Avoid overwatering}

Overwatering established landscape plants is more common than underwatering. While newly planted ornamentals and garden plants require frequent light irrigations due to small, compact root systems, established plants should not be watered every day. They do much better with deep and infrequent irrigation.

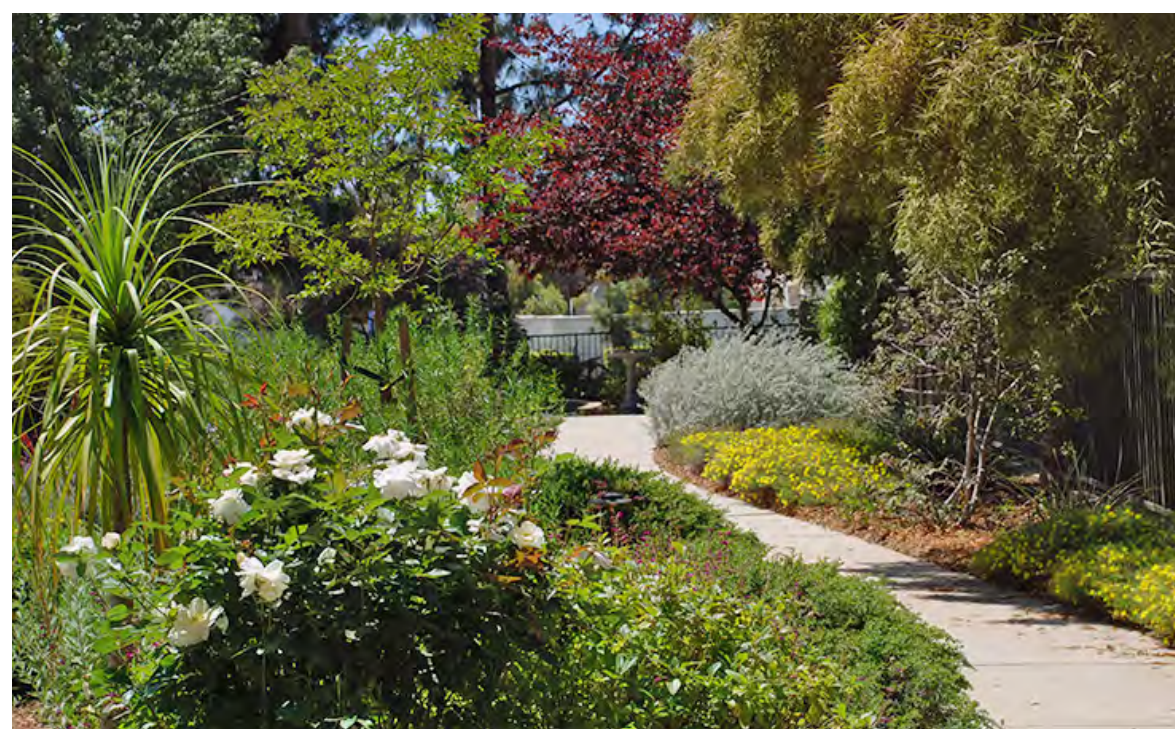

Figure 3. An attractive, water-efficient, low-maintenance landscape. Source: Courtesy of Western Municipal Water District (Landscapes Southern California Style). 
Know how much water to apply and when to apply it

Become familiar with the water needs of plants growing in your climate. The water requirement of a plant is closely linked to its evapotranspiration (ET) rate. ET is the loss of water into the atmosphere from the soil and plant surfaces (evaporation) and from the plant actively taking up water (transpiration). The water requirement of a plant depends on many factors, including solar radiation, air temperature, relative humidity, wind speed, type of soil, root depth, foliar density, microclimate, and stage of growth.

As figure 4 illustrates, a plant adapted to the San Francisco Bay Area, Riverside, and Palm Springs areas will require the most water in Palm Springs due to its higher ET rate in the hot desert. Adjusting the amount of water you apply to your landscape based on seasonal changes can greatly reduce water waste and maintain the health of the plants. A common mistake is to forget to adjust your automatic timer downward going into the fall.

A straightforward approach to help you apply the right amount of water to your landscape when it is most needed is to use the "feel test." Get your hands dirty! Dig a small hole 6 to 8 inches deep around annuals and at least a foot deep around large shrubs and trees, being careful not to disturb plant roots. Grab a handful of the removed soil and squeeze. Soil that is wet enough but not too wet will feel like a well-squeezed sponge. Soil that falls apart easily is a little too dry and should be irrigated. If a lot of water oozes out, wait a few days before you water. Established trees can often go much longer between irrigations than more shallowly rooted annuals.

\section{Know your soil type}

Keep in mind that sandy soils hold less water than heavier soils containing clay, and they need to be irrigated more frequently. Sandy soils also take in water and drain much faster than clay soils. This can lead to water and nutrient loss below the root zone and potential water pollution. Clay soils, on the other hand, take in water much more slowly and are more likely to incur runoff from the soil surface. This can also result in water pollution and wasted water. An easy way to determine what type of soil you have is to expand the feel test described above. Soil containing clay will form a ribbon as you squeeze it between your thumb and forefinger, while sandy soil will crumble and not ribbon (see fig. 12).

\section{Hydrozone}

Place plants with similar water needs together so they can be irrigated on the same schedule, without underwatering the thirsty plants or overwatering the more conservative water users. For help in determining water needs of specific plants, refer to the resources listed in the section "Select Plants Recommended for Your Climate and Microclimate" above.

\section{Add organic matter to your soil}

Before planting ornamentals other than trees, consider mixing 1 to 3 inches of organic matter, such as compost, evenly into the soil at least 6 inches deep. (Sandier soils benefit from 2 or 3 inches, while clay-based soils require only 1 to 2 inches.) Organic matter added as a soil amendment increases the water-holding capacity of

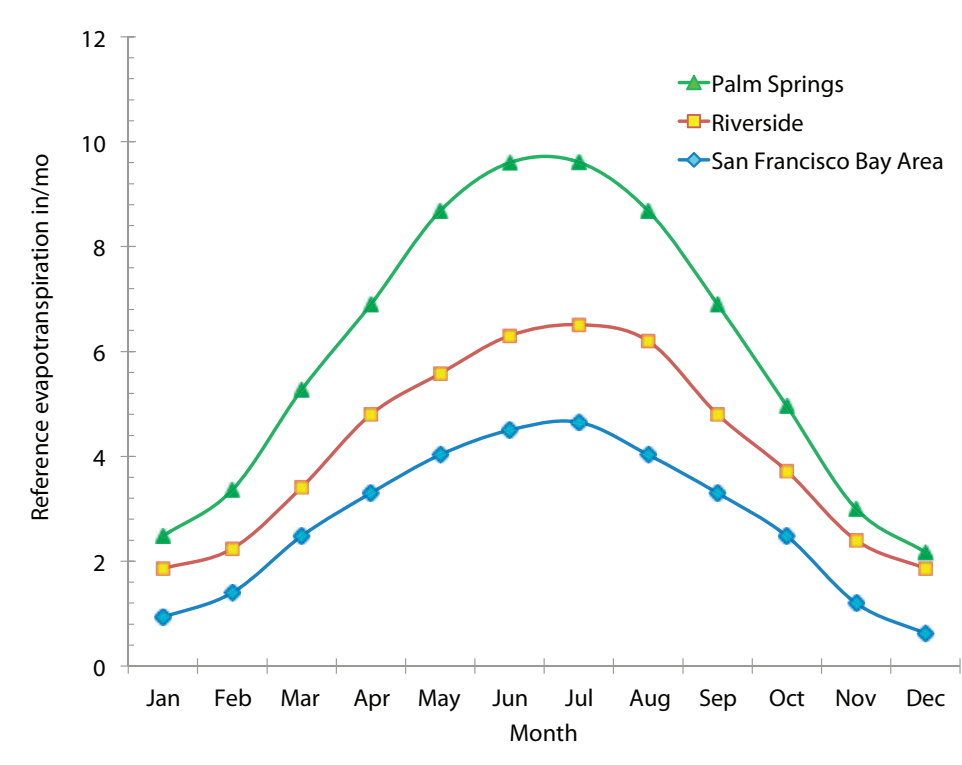

Figure 4. The same plant growing in southern California inland valley or desert areas requires more water than if grown in the San Francisco Bay Area due to higher rates of evapotranspiration. Source: Richard Snyder, Department of Land, Air and Water Resources, University of California, Davis. 
sandy soils. This reduces the chance of water loss below the root zone, improving drainage in clay soils and reducing the chance of runoff. While organic matter makes a great soil amendment for small woody ornamentals and garden plants, it should not be used in tree planting sites. This is because roots often prefer the higher-quality amended soil and grow outward instead of downward, resulting in poor anchorage and support for the maturing tree.

Mulch

Apply 3 to 4 inches of mulch (e.g., wood chips, straw) on the top of soil around your landscape plants (fig. 5). Be sure to keep mulch at least 1 foot away from tree trunks to avoid causing wet crowns, which are subject to disease-forming pathogens. Mulch reduces soil evaporation, controls weeds, reduces erosion, buffers soil temperature, reduces compaction, and prevents bark damage on trees from string trimmers and lawnmowers. It is important to recognize that organic mulches decompose over time and need to be supplemented regularly to remain effective. While inorganic materials (e.g., rocks, pebbles,

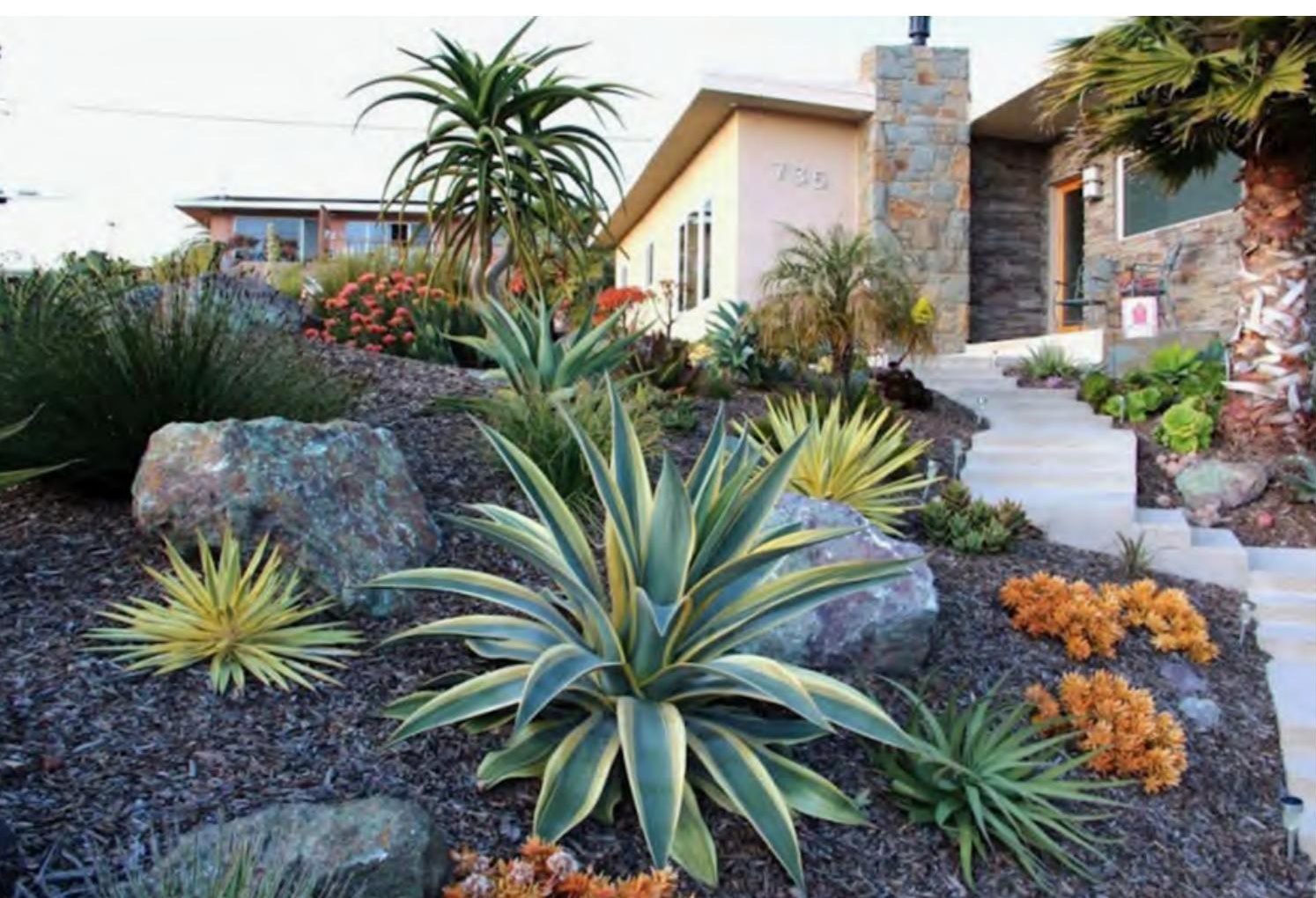

landscape fabrics, shredded tires) do not need to be replaced often due to decomposition, they are frequently more expensive and provide no benefits to soil health.

\section{Drip irrigate}

Drip irrigation can significantly reduce water waste and be used successfully in any part of your landscape not planted with a lawn or groundcover. Drip emitters apply moisture directly into the root zone of plants, minimizing evaporation of water from the soil surface between plants. Soaker hoses, drip tape, porous pipe, minisprinklers, and laser tubing are all examples of drip systems. They are not difficult to install. Many do-it-yourself stores and irrigation supply companies offer free guidelines detailing their installation. If you would rather not take on this project on your own, you can hire a landscaper and irrigation specialist to provide this service.

Use the "Lawn Watering Guide"

When irrigated correctly, warm-season lawns (e.g., bermudagrass, zoysiagrasss) are relatively drought resistant, requiring 20 to 30 percent less water than cool-season species (tall fescue, annual and perennial ryegrasses, and Kentucky bluegrass). It is not the grass itself that wastes the water but rather the inefficient irrigation systems that apply water unevenly across the lawn. The Lawn Watering Guide for California (Hartin et al. 2001) lists the number of minutes per week to water your warm- or cool-season lawn based on its seasonal water demand and the amount of water your system puts out. The guide explains step-by-step how to conduct a "can test" to determine your system's output rate and evenness of application, and it lists tips to improve the distribution uniformity of the system. Use of this guide can reduce water waste significantly and improve the health of your lawn. (Most groundcovers perform very well under the warm-season regime in the guide also.)

\section{Cycle water when needed}

Large amounts of water are often wasted due to water running off the surface of clay soils and down slopes, particularly in lawns

Figure 5. A 3-inch layer of wood chip mulch around landscape plants decreases soil evaporation and reduces weed growth and erosion. Photo: Gabriel Frank, http://www.gardensbygabriel.com. 
watered with sprinklers. Applying water in cycles supplies the same amount of water needed under ordinary conditions over two or more applications as close together as possible before soil dries out. Irrigate initially until the first signs of runoff occur, allow the water to soak in, and then irrigate the same area one or two more times until the total required minutes listed in the Lawn Watering Guide for California referenced above are reached.

Consider installing a "smart" irrigation controller

These devices automatically program a prescribed number of minutes onto your irrigation controller, based on real-time or historical data. Seasonal adjustments are made automatically. Smart systems may also include settings for plant type and density, as well as microclimate factors. While these systems can reduce water waste, they are only effective if accurate information is used in their programming. Whether you choose a smart controller or one you manually program, a rain sensor should be attached to your controller to shut your system off in the event of significant rainfall.

\section{Learn to recognize plant drought symptoms}

Under drought, foliage may initially lose its luster, shrivel, and droop. Turf will hold a footprint. Over time, plant growth is reduced. Stems and twigs toward the outer parts of the plant begin to defoliate and may eventually die. Finally, the entire plant may die if water is not provided. Ideally, irrigation should be applied before plants show pronounced symptoms.

\section{Water early in the morning}

Water before or shortly after sunrise to avoid water loss from soil evaporation, which otherwise would occur during the heat of the day. If you're not ordinarily up when your system turns on, it's a good idea to occasionally set your alarm earlier than usual so you can make sure that everything is in good working order.

\section{Collect and reuse rainwater}

Use cisterns, barrels, or storage tanks to collect water, and consider diverting your downspout into a covered barrel. Reuse the captured water to irrigate nonedibles, such as hanging baskets and container plants, or connect it to a drip irrigation system. Make sure that collection vessels are covered to prevent mosquito breeding and entry by animals and children. Check with your local water agency for more information and to inquire about local ordinances restricting the collection and reuse of rainwater.

Repair worn and broken irrigation system components regularly Both sprinkler and drip irrigation systems should be checked regularly for broken or inoperative components and leaks that may otherwise go undetected. Examples are clogged nozzles, worn nozzles, tilted sprinkler heads, and heads in the same zone with varying precipitation (output) rates. Also look for signs of leaky valves in your control box, such as water continually oozing around sprinkler heads. Correcting these problems often reduces water waste by at least 20 percent.

Use a broom rather than a hose to clean patios, driveways, and walkways Sweeping provides an opportunity for exercise as well as a reduction in water waste and potential pollution of waterways from drainage water containing fertilizers and pesticides.

\section{Consider using graywater to irrigate your landscape}

The use of graywater (also spelled greywater, gray water, and grey water) to irrigate landscape plants is becoming popular throughout California and other arid states. Using graywater to irrigate landscape plants can save water, reduce water bills, and conserve electricity by recycling water otherwise destined for a wastewater treatment plant. Since an estimated 30 to 50 percent of home water use produces graywater, significant savings can be realized by reusing this source of nonpotable water to irrigate landscape plants. A typical household (2.6 people) produces an average of 90 gallons of graywater each day. While most graywater systems do not supply enough irrigation water to irrigate an entire traditionally landscaped yard, many supply one-half to three-quarters of the needs of a dripirrigated, water-efficient landscape.

In California, graywater is defined as "untreated wastewater that has not been contaminated by any toilet discharge, has not been affected by infectious, contaminated, or unhealthy bodily wastes, and does not present a threat from contamination by unhealthful 
processing, manufacturing, or operating wastes. Graywater includes, but is not limited to, wastewater from bathtubs, showers, bathroom washbasins, clothes washing machines, and laundry tubs, but does not include wastewater from kitchen sinks or dishwashers" (California Department of Housing and Community Development).

A permit is no longer required for the installation of the following single- or two-family residential graywater irrigation systems if other conditions under section 1603A1.1 of the California Department of Housing and Community Development (HCD) are met:

- a simple clothes-washing graywater system, as long as it does not require cutting of the existing plumbing piping

- a single-fixture system that collects graywater from one plumbing fixture

All other systems require a construction permit prior to erection, retrofitting, construction, and installation, as stated in the actual code. The full text of the residential graywater use standards can be viewed at the HCD website, http://www.hcd.ca.gov/codes/shl/ Preface_ET_Emergency_Graywater.pdf. (Because these regulations may change at any time, always check with the HCD and local enforcement agencies in your county and city before developing plans for or installing a graywater system.)

Laundry-to-landscape graywater systems are relatively inexpensive and easy to install. Simply attach the hose exiting the clothes washing machine to a valve that separates graywater from water destined for the sewer. The graywater is diverted through a 1-inch main irrigation line with $1 / 2$-inch tubing outlets placed throughout the landscape, terminating in a valve box in a mulch basin. The washing machine pump distributes water directly to the landscape with no filter. Keep in mind that salt- and boron-free liquid laundry detergents should be used if the graywater is intended for irrigating the landscape. Chlorine bleach should be avoided.

Mulch basins receive and distribute graywater to plant root zones; they need to be sized correctly to prevent surface ponding. Basin size depends mainly on soil texture. For example, graywater percolates quickly through sandy soils, requiring minimal mulch. In slower-percolating clay loam soils, a larger mulch basin is required around the valve box to prevent graywater ponding. Large woodchip mulch is more durable and longer lasting than smaller woodchip mulches or shredded fiber.

Graywater should only be applied to nonedible ornamental plants and never directly to edible plant parts or root crops. It is also important to avoid splashing graywater on edible plants neighboring nonedible ones. Do not apply graywater through sprinkler systems, since droplets containing harmful microbes can become suspended in the air and breathed in.

It is important to note that because of the recent easing of restrictions regarding graywater reuse, research pertaining to the long-term impacts and risks of graywater use on plant health, human health, soil chemistry, and ground and surface water quality is very limited. Potential risks include those related to human health, plant health, soil chemistry, and water quality.

Due to these potential risks, always take the following precautions:

- Carefully label all valves and pipes associated with your graywater system, and prevent backflow.

- Do not store graywater for more than 24 hours.

- Wear gloves and do not come into direct contact with graywater.

- Do not let graywater pool or run off from the soil surface, potentially contaminating surface water or coming into contact with well water.

- Do not irrigate edibles with graywater or allow it to splash on neighboring edible plants.

- Do not use sprinkle irrigation on turfgrass or groundcover areas with graywater, since potentially harmful microorganisms can remain on the surface.

- Do not use graywater contaminated with human waste, infectious disease organisms, grease, paint residue, gasoline, solvents, or other chemicals found in household and industrial products.

- Keep the graywater system simple, and avoid systems requiring heavy upkeep and maintenance. Contact a professional with experience in designing and installing graywater systems if you lack the specific knowledge or time to undertake the project yourself. 


\section{Protect Water Quality}

Degradation of inland and coastal waterways is of great concern in California. Runoff water carrying suspended solids, pet wastes, pesticides, and fertilizers pollutes waterways and can occur in high enough levels to impair water quality and harm aquatic life. Anytime you apply a fungicide, insecticide, herbicide, or even many types of fertilizers, water quality is at risk. To avoid using a chemical in a way that may contribute to water pollution, always prioritize best management practices described in this publication and other UC ANR publications (see the UC ANR online catalog website, www.anrcatalog. ucanr.edu), as well as UC Integrated Pest Management (UC IPM) publications (see the UC IPM website, www.ipm.ucdavis.edu).

Fertilizers are frequently applied to urban landscapes to improve plant growth, performance, aesthetics, and function. Water pollution can occur when certain elements enter waterways from soil runoff and groundwater leaching due to higher than recommended application rates and applications made prior to or during heavy rain. Overuse and misapplication of nitrogen $(\mathrm{N})$ and phosphorus $(\mathrm{P})$ are particularly problematic and can readily lead to water quality degradation and harm to aquatic life. Grass clippings and fertilizers should be kept off impervious surfaces, such as driveways and sidewalks, due to the risk of runoff and potential pollution of waterways.

Pesticides are sometimes applied to urban landscapes to control weeds, diseases, insects, and other pests. Overuse or misuse of pesticides and improper disposal and storage can negatively impact public health; reduce or eliminate populations and diversity of beneficial insects; result in pollination problems and honeybee losses; impact the health and reproduction of birds and other wildlife; and contribute to water and air pollution.

\section{Recommended Fertilizer and Pest Management Practices That Favor Environmental Protection}

\section{Avoid Overfertilizing}

You may be fertilizing your landscape too much! Landscape plants generally do not need regular fertilization. While all plants require nutrients, applying more than is necessary contributes to the potential for polluted runoff. It also leads to flushes of new growth that require more water.

Nine essential elements (referred to as macronutrients) are required for plant growth: nitrogen, phosphorus, potassium, calcium, magnesium, sulfur, carbon, hydrogen, and oxygen. The last three are readily available in air and water. Eight other essential elements (micronutrients) are required in small amounts by plants: iron, manganese, zinc, boron, molybdenum, copper, chlorine, and nickel.

Nutrient deficiencies are uncommon in established landscape plantings (other than palms and turf and plants growing in soils lacking adequate organic matter). In fact, applying high rates of nitrogen-containing fertilizer may stimulate excessive, undesirable growth.

The decision to augment the inherent fertility of a landscape soil should be based on how healthy the plants look and perform, as well as the results of soil and tissue tests performed by a reputable laboratory. Fertilizer applications are sometimes beneficial for recently planted non-native landscape plantings, particularly those growing in sandy soil with little or no organic matter. While common symptoms of nutrient deficiencies include smaller than normal yellowish leaves and stunted shoot growth, similar symptoms are the result of other factors. These include root or crown diseases resulting from overwatering, insect damage, or environmental problems. Correctly identifying the cause of the symptoms before routinely applying nutrients is crucial for maintaining plant health and preventing surface and groundwater pollution from unnecessary fertilizer applications.

Be aware that a high soil $\mathrm{pH}$ may create a situation where soil nutrients are tied up in the soil and unavailable to the plant. A good example of this is iron deficiency, which is a relatively common nutrient deficiency in high-pH soils. Reducing the $\mathrm{pH}$ to a more neutral condition will remedy this situation.

Although, as previously stated, nitrogen deficiencies are relatively uncommon in most established landscapes and overuse can lead to nitrate pollution in ground and surface waters, a discussion of quickly available (fast-release) and slowly available (slow-release) 
forms of nitrogen is important. This distinction refers to how fast the applied nutrients are available to the plant and the length of time they remain available.

While slow-release nitrogen products cost more than quickrelease products, they are preferred in sustainable landscapes because they require less frequent application, provide an even supply of nitrogen, and are less likely to lead to water pollution. They have a lower burn potential and are especially recommended for sandy soils, which are highly leachable. In addition, they are preferred when "grasscycling" (leaving cut grass clippings on the lawn as you mow) to prevent flushes of rapid growth.

Longer-chained urea formaldehyde products such as Nitroform and Hydroform, as well as natural organic products such as bone meal and activated sewage sludge, are examples of slowly available nitrogen products that are dependent on high temperatures and bacterial activity for release. Polymer-coated/ sulfur-coated urea (SCU) and isobutylidene diurea (IBDU) are less temperature dependent. Coated urea products slowly discharge urea through cracks in the coating. The urea enters the soil solution over a 2- to 3-month period.

Sources of nitrogen that are quickly available include inorganic salts such as ammonium sulfate, ammonium nitrate, and potassium nitrate, and organic forms such as urea and methylol urea. They are all highly water soluble. In California, ammonium sulfate is often the preferred quick-release fertilizer for general use due to its acidifying effect on our high-pH soils. It is important to remember that while fast-release fertilizers result in a more immediate response than do slow-release forms of nitrogen, greater skill is needed in their application to ensure even distribution and prevent problems resulting from overapplication, such as surface and groundwater pollution.

\section{Limit the Use of Pesticides}

While pesticides are formulated to kill or injure pest organisms, most have some negative impacts on beneficial organisms and wildlife as well. Pollinators, natural enemies of insect pests, beneficial soil microorganisms, worms, and decomposer organisms are all essential components of sustainable landscapes and can be compromised and severely limited by the application of pesticides, particularly those that persist in the environment for weeks, months, or years. The use of pesticides in a sustainable landscape should be limited to situations where they are truly needed. If pesticides are necessary, choose products that pose the least threat to the environment, nontarget organisms, and human health.

Many garden and landscape pests can be managed with nonchemical practices, which should always be a first line of defense. Other pests can be controlled with pesticides that have minimal impact on the environment. Using an approach based on integrated pest management (IPM), which relies on preventing pest problems in the first place and incorporates multiple environmentally sound management tools, is the best way to protect your garden and the environment. (Please refer to the "Integrated Pest Management" section below for more specific information.)

In the rare instance that a pesticide is warranted, follow all label directions and do not apply the pesticide when it is windy or rainy or on hard surfaces, such as driveways and sidewalks. Prevent pesticides from entering storm drains or creeks and other waterways during rain or irrigation, and dispose of them properly at an approved household hazardous waste site. Be aware that some pesticides are more easily carried in surface runoff than others and therefore have a greater potential to move off-site during irrigation or storms. Carefully study the information on potential hazards of specific household and landscape pesticides-including risks to pollinators, humans, and water quality - available on the Landscape and Garden Pesticide Active Ingredient Database on the UC IPM website, http://www.ipm. ucdavis.edu/PMG/menu.pesticides.php.

\section{Practice Integrated Pest Management}

Many alternatives to applying pesticides exist. Most pest problems in urban landscapes can be prevented or reduced to acceptable levels through proper plant selection and the use of recommended cultural 
practices. Integrated pest management (IPM) minimizes damage from insects, diseases, weeds, nematodes, and other potentially harmful organisms through largely preventive measures. IPM is an important component of sustainable landscaping. It reduces waterway pollution, protects populations of beneficial soil microbes, encourages desirable wildlife, and conserves energy required for pesticide manufacturing.

While relevant IPM practices are mentioned throughout this publication in appropriate sections, a discussion of these practices as a separate unit is important in order to illustrate the importance of IPM as a planned component of sustainable landscaping. Important IPM practices include providing optimum growth conditions for plants by matching plants to their preferred climates and microclimates; selecting disease-resistant varieties; providing well-drained, healthy soil; providing the right amount of water and nutrients; and eliminating habitats or conditions that favor pests. Low to moderate levels of many pests often can be tolerated and no control is warranted. Also, many insects and disease-causing pathogens are controlled by naturally occurring biological control agents or suppressive soils in gardens and landscapes that are managed sustainably (fig. 6).

An underlying principle of IPM stresses pesticide use only as a last resort. If a pesticide is necessary, choose a product that will create the least environmental disruption, limit hazards to human health, and maintain the integrity of the ecosystem by targeting only the pest. For example, a broadly toxic insecticide may also kill natural enemies, pollinators, or wildlife. The negative impact that some pesticide products have on the environment, as well as

Figure 6. Preserving naturally occurring pest predators such as this ladybeetle is an important component of a sustainable landscape. Photo: J. K. Clark. on human and animal health, can be significant. Likewise, applying a pesticide before the problem is accurately identified is also an environmentally unsound practice, as is applying a pesticide on a plant to control a short-lived problem that will self-correct during a change in season or weather pattern or be controlled by natural enemies.

\section{IPM programs combine a variety of management options to} maximize effectiveness

- Biological control relies on natural enemies (e.g., predators, parasites) to control insect and mite pests. Another example is soil microorganisms in healthy soils that reduce soilborne plant pathogens.

- Cultural controls (or best management practices) prevent and reduce pest problems by promoting a favorable environment for the plant and an unfavorable habitat for the pest. Examples include providing well-drained soil and irrigating established plants deeply and infrequently to prevent disease-causing organisms that thrive under wet conditions. Another example is installing drip irrigation to eliminate soil surface moisture, which favors weeds, snails, slugs, and other pests.

- Mechanical and physical controls kill pests directly or make the environment unsuitable for them. Examples include using traps for rodent control, removing an insect from a plant by hand, handweeding and using mulches for weed control, and establishing barriers such as screens to exclude birds and insects.

- Pesticides can be part of IPM programs as well, but only as a last resort. Use pesticides only if nonchemical methods are ineffective. Choose products that have the least negative impact on beneficial insects, pollinators, and other nontarget organisms.

Before any control measure is selected, correct identification of the problem is essential (fig. 7). Some problems require no control other than waiting it out, while others require a more active response. Many symptoms of plant decline thought to be due to pests are actually the result of an environmental or physical stress, such as an unusually hot or cold season, too little or too 
much moisture, root damage due to construction, compacted soils with poor aeration, or mineral or pesticide phytotoxicity. In fact, most problems leading to unhealthy plants are due to soil and water management issues rather than pests. Following the recommended practices in the section "Water Management" will prevent many of these conditions from occurring in the first place.

\section{Biotic pest problems and IPM} solutions

Many of the truly biotic pest problems that do occur in home landscapes are due to diseases, insects, and weeds. An overview of each follows:

Plant diseases. Plant diseases disrupt normal, healthy plant growth and, when severe enough, can kill plants. Plant diseases occur when a plant-pathogenic microorganism (e.g., fungus, virus, or bacterium) interacts with a host (susceptible plant) under environmental conditions that favor disease development. The disease triangle depicted in figure 8 illustrates how all three factors must all be present for a disease to occur. As a home landscaper or gardener, you have control over selecting a disease-resistant host plant and promoting healthy plant growth that favors the environment. An example is choosing one of the newer crape myrtles resistant to powdery mildew (Lagerstroemia indica) (proper host selection) and not overirrigating it (environmental best management practice).

You can prevent or effectively manage most diseases by implementing appropriate cultural management methods, such as the following:

- Choose plants based on your climate and microclimate.
- Select healthy plants that are not root bound and do not appear diseased.

- Transplant container plants so that the uppermost soil level remains the same as it was in the pot; avoid burying plant crowns or not planting deeply enough.

- Keep roots of newly transplanted trees, shrubs, and groundcovers evenly moist until established.

- Cut back on frequency of irrigation, but water more deeply once roots and plants mature.

- Provide adequate nutrition but avoid overfertilization.

- Follow recommended pruning practices.

Sanitizing pruning tools between cuts in rubbing alcohol or a solution of one part bleach to nine parts water can prevent the spread of disease when pruning affected plants. Lubricate tools after sanitizing to avoid corrosion.

It is important to conclusively identify the causal agent resulting in symptoms of decline before deciding on a treatment. Many abiotic (nonliving) disorders, such as drought stress, air pollution damage, and damage due to soil compaction and poor

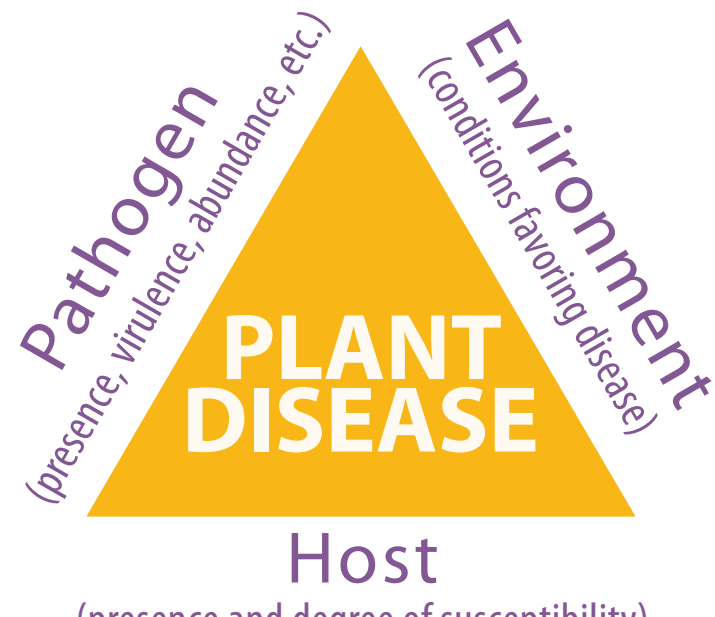

Figure 8. The disease triangle illustrates the importance of plant selection and environments conducive to healthy plants in order to avoid disease-causing pathogens. Source: UC IPM website, http://www. ipm.ucdavis.edu/PMG/

(presence and degree of susceptibility) PESTNOTES/pn7497.html. 


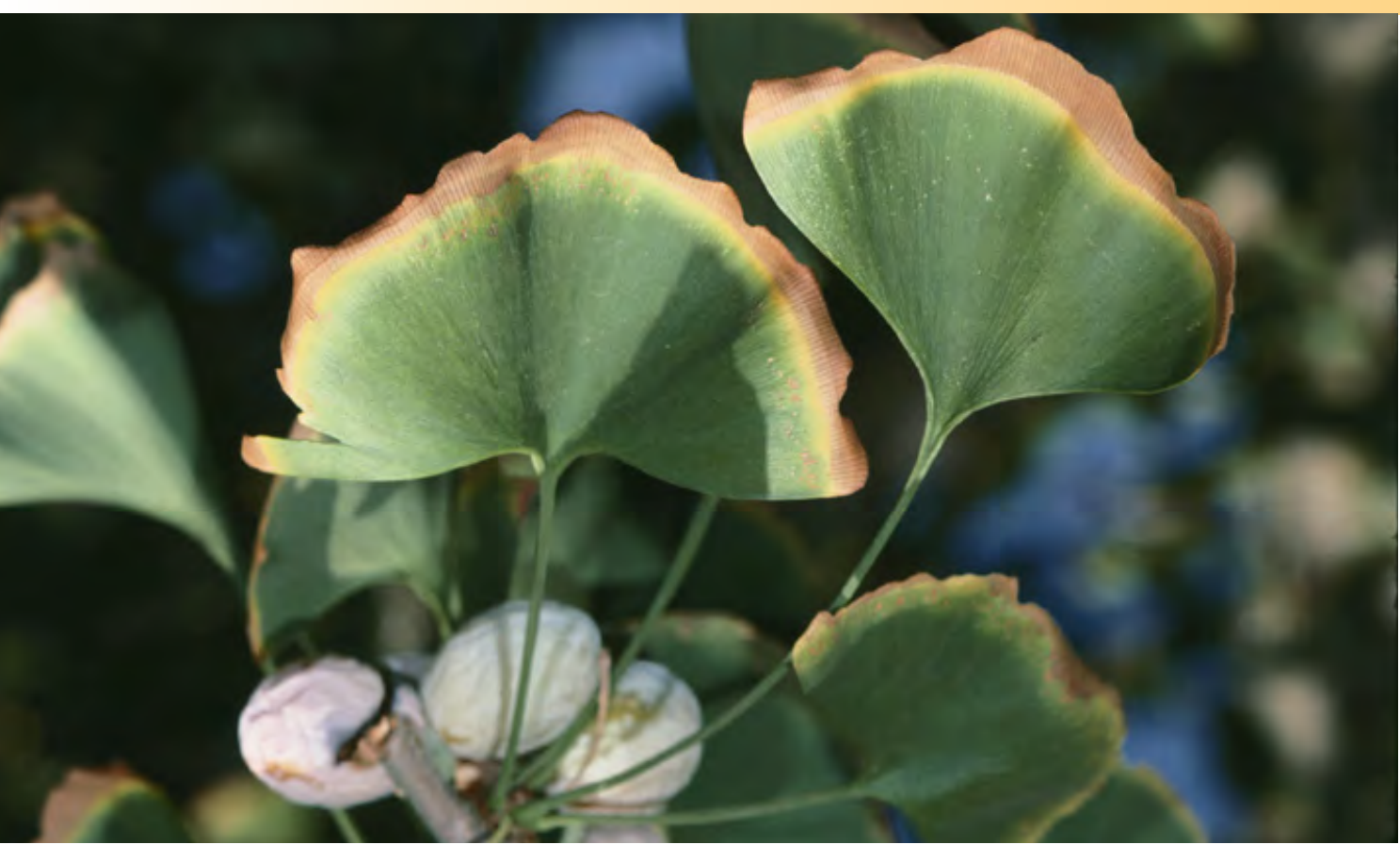

Figure 9. Abiotic disorders may mimic symptoms caused by disease. Shown here are yellow margins on maidenhair tree (Gingko biloba) caused by mineral toxicity. Photo: J. K. Clark.

aeration in the root zone, mimic those caused by diseases (fig. 9). Improper identification of the causal agent may result in inappropriate treatment. In these cases, you will not only fail to solve your problem but will waste money and may unintentionally worsen the situation.

Arthropods. Many insects, mites, and spiders live in our landscapes. Many are beneficial rather than harmful. Removing or killing beneficial insects will almost always result in outbreaks of insect pests. It is critical that you properly identify any suspected insect and related damage before deciding on a control measure. In some cases, there may be natural predators that you can introduce into your landscape if high enough populations are not found naturally to remedy the situation.

Beneficial insects include pollinators such as honeybees and other native bees; insect predators such as ladybugs, soldier beetles, wasps, lacewing larvae, and predacious mites; and parasites such as braconid and chalcid wasps and tachinid flies. Predator and parasite species play a vital role in maintaining insect pests at tolerable levels. If these beneficial species are killed off by pesticides, a large pest problem can occur later in the season. In addition, misuse and overuse of pesticides can kill pollinators. And reduction in pollinator populations can have a significant negative impact on the production of many types of produce. For additional information, refer to the UC ANR Natural Enemies Gallery on the UC IPM website, http://www.ipm.ucdavis.edu/PMG/NE/.

Following recommended cultural practices, such as applying the correct amount of water and fertilizer and avoiding soil compaction and construction activities close to trees, is a very effective means of preventing insects from causing significant damage. A plant weakened from an environmental stress or disease is much more susceptible to other stressors, such as insects, than a healthy plant. For example, bark beetles are much more likely to seriously damage drought-stricken trees than trees with adequate water.

Implementing sound sanitation measures will also significantly reduce insect problems. Woodpiles can attract termites, carpenter ants, and even rats. Always store wood off the ground and away from outer walls and the house. Trim vegetation that touches the house. Remove debris, rocks, and bricks where pests such as sow bugs, millipedes, snails, and slugs hide. Also, remove diseased plants, tree trimmings, and fallen fruit and leaves, since they all can harbor pests. Handpicking, trapping, and washing pests off plants with a forceful spray of water are also good ways to reduce some insect problems.

Regularly check plant parts for signs of insect and mite feeding or tunneling: foliage (holes, skeletonized leaves, browning); trunk (holes, cankers, oozing sap, dieback); and roots (wilting, stunted growth, cut-off or chewed appearance). Then identify the pest based on the damage you see: chewed foliage (beetles, caterpillars, grasshoppers); chlorotic, yellow foliage (aphids, mites, thrips, etc.) (fig. 10); trunk holes (borers); and root damage (grubs).

A number of low-toxicity insecticides are effective and consistent with sustainable landscape principles. They can be 


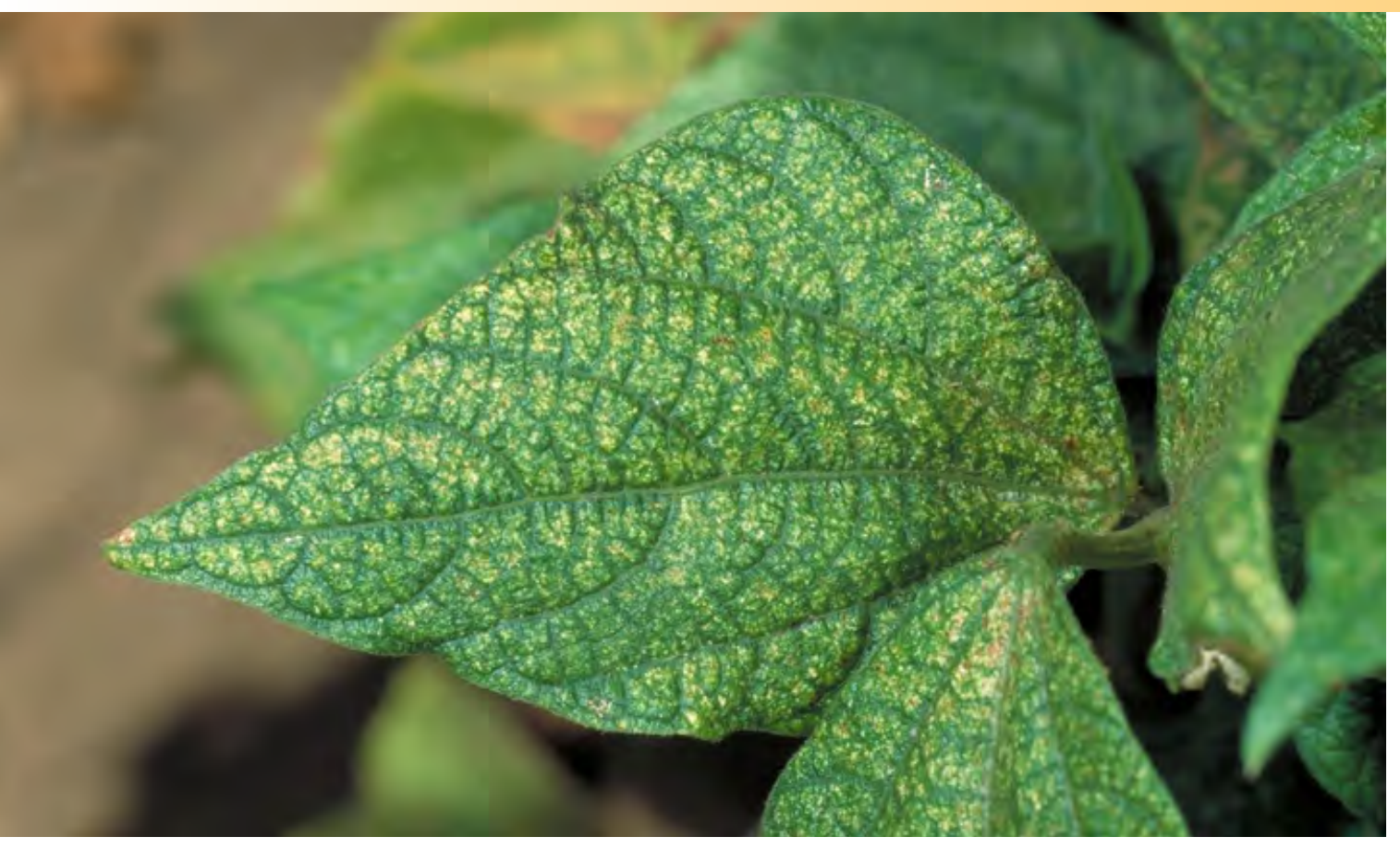

Figure 10. Spider mites cause yellowing or stippling of leaves. Photo: J. K. Clark.

used when an insecticide spray is necessary due to high levels of a pest that persist even after nonchemical approaches have been implemented. Insecticidal oils (including mineral- and plant-based oils like neem) control aphids, whiteflies, mealybugs, scale insects, lacebugs, psyllids, thrips, and spider mites. Microbial insecticides, which are derived from microoganisms that cause disease only in specific insects, include Bacillus thuringiensis products for caterpillars and fungus gnats as well as codling moth granulosis virus. Spinosad is a microbial-based insecticide that controls caterpillars, spotted-wing Drosophila, leafminers, and thrips, but it can harm some beneficial insects. Be aware that these products are relatively short-lived and may need to be applied several times if populations are high. Follow label instructions carefully.

Weeds. A weed can be defined as a plant growing in the wrong place. Thus, weeds not only include pesky plants such as dandelions and nutsedge, but also squash and tomato seedlings germinating in your compost pile or turfgrass growing in your planting beds. Brushy weeds such as blackberry and poison oak can be very difficult to manage.

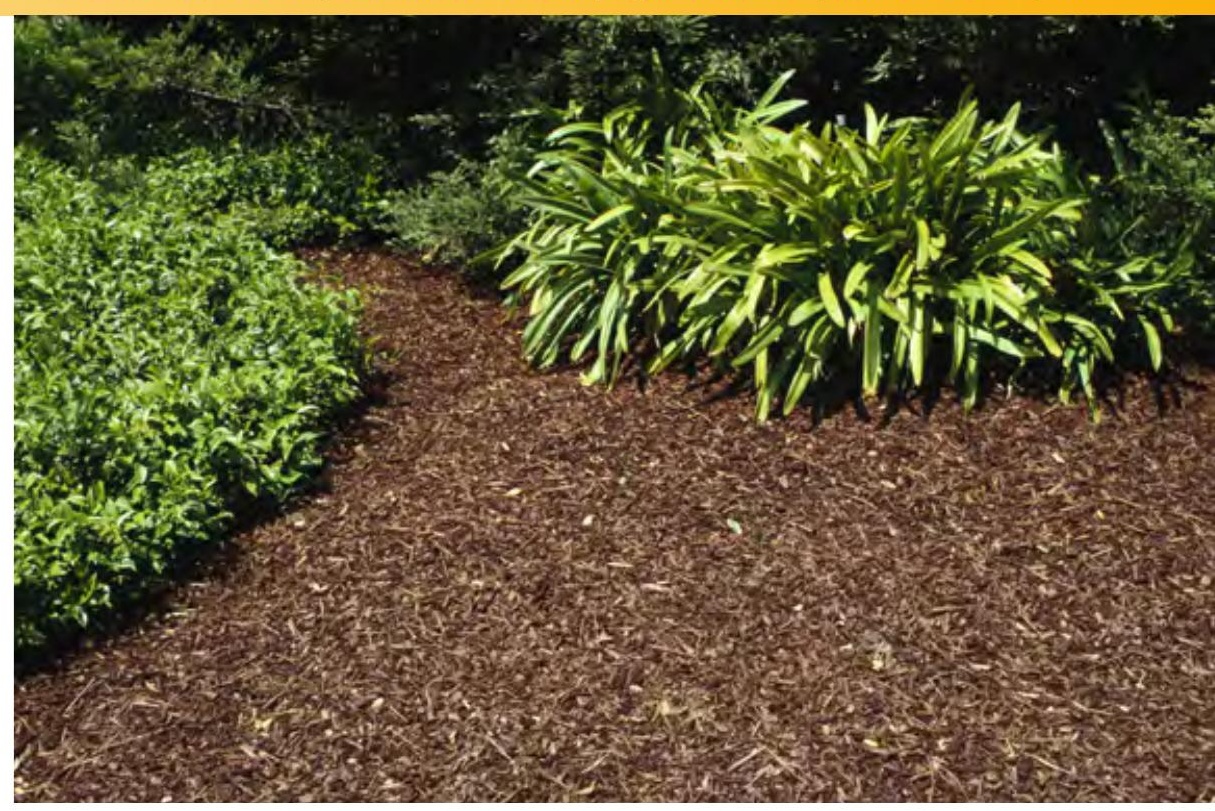

Figure 11. Organic mulches, with or without landscape fabric beneath, provide an excellent way to manage weeds sustainably. Photo: J. K. Clark.

Like other pests, weeds can be controlled best through prevention. An excellent example is adding a 3- to 4-inch layer of organic mulch on top of a clean, weed-free soil surface (fig. 11). Mulch prevents weed seeds from germinating in the first place. Weed control fabric placed over the soil, topped with an organic mulch, also works well.

Drip irrigation is another tried and true way to reduce weed seed germination, since it keeps the soil between plants dry. Be sure to control encroaching weeds that sprout around emitters, however. Also, be sure to maintain a dense cover of plant material to reduce weed seed germination when irrigating lawns and groundcovers not adapted to drip irrigation.

Other ways to restrict weeds from sprouting are to make sure that organic products used as mulch and soil amendments, such as wood chips and compost, are weed-free and to patch cracks in driveways and walkways subject to weed encroachment.

It is very important to prevent the weeds that do survive from producing seed. Many weeds produce literally thousands of viable seeds. Weeds are easiest to pull when they are small and growing in moist soil. Make sure to hand pull or dig out the roots of annuals 
before they go to seed. If perennial weeds are a problem and you can't dig up the entire root system, deprive them of energy by cutting the entire plant off at ground level and covering the area with 3 to 4 inches of mulch. If they resprout, cut them back to the ground right away to further deplete energy before leaves develop. Repeat as necessary. You will eventually win the battle!

Hand-pulling weeds or using cultivation tools is a primary weed control method. Use a shovel, hoe, or trowel to remove pesky weeds you can't remove by hand. Avoid planting until you control any secondary crop of weeds that may germinate once seeds are brought to the soil surface from soil turning. Specialized tools like dandelion tines are useful and do not bring seeds to the surface.

Another recommended weed control option involves a process called soil solarization. It works best in inland and desert areas in the summer but can also be effective along the coast in late summer. Soil solarization is effective at killing most weed seeds in the top few inches of soil by using heat from the sun. Successful solarization relies on wetting the soil several inches deep and promptly placing and securing the edges of a 2-mil piece of clear plastic over the soil surface. Remove the plastic in 6 weeks to 2 months. Exercise caution to avoid turning over additional soil that may contain viable weed seeds during the planting process following the solarization process. For more information on this practice, go to the Soil Solarization for Gardens \& Landscapes Pest Note (Stapleton et al. 2008). Using low-toxicity, organic herbicides such as those containing clove oil (Burn Out II) or soap (Concern Fast Acting Weed Killer) is also an effective weed control practice. However, these products kill only the top portion of the weed, and the roots or crowns of perennials or older plants will likely resprout. Older weeds may require repeated applications.

Caution: when spraying any type of pesticide, follow label directions carefully. Avoid applications during windy weather, and protect landscape plants from coming into contact with the chemical. Keep pets and people out of the area until the product has dried.

Recommended pest management methods vary from species to species. Visit the UC IPM Home, Garden, Turf \& Landscape Pests website, www.ipm.ucdavis.edu, for environmentally sound pest management practices for hundreds of garden and landscape pests.

\section{NuRTURE THE SOIL}

A basic understanding of your landscape soil and how to nurture it is important for successful sustainable landscaping. Because what occurs in the soil is below the surface and not visible, it is easy to overlook the importance of how soil texture and structure relate to water and nutrient management and how activities such as construction and heavy foot traffic negatively impact plant health. All too often, by the time these conditions result in aboveground plant decline, it is too late to remedy the situation.

The water-holding and nutrient-storing capacities of a soil are largely determined by its texture (particle size representing the sand, silt, and clay content) and structure, which relates to how the textures hold together. Fine-textured soils containing relatively high percentages of silt and clay hold more water and nutrients than coarser-textured, sandier soils, but they drain more slowly. They are also more prone to poor aeration and downward root penetration (fig 12). Generally, the higher the sand content of a soil, the more freely draining and better aerated it is. Soil aggregation is a beneficial process governing how groups of soil particles bind together. The pore space between the aggregates is important for water retention and for air and water exchange. Aggregation is poor in very sandy soils void of organic matter and clay. Soil aggregation can be enhanced by the addition of compost (discussed elsewhere in this publication) and by root growth, as well as wetting, drying, freezing, and thawing cycles. Tilling a soil too often can destroy aggregation and should be avoided.

Maintaining a deep and uniform soil free of layered horizons of various textures is a key component of healthy, sustainable landscapes. Layered soils result in poor infiltration and downward movement of water, preventing water from moving into a deeper horizon (layer) until the upper horizon reaches maximum waterholding capacity. Layered soils often result in shallowly rooted plants. They are particularly problematic for trees, which require deep, homogeneous soils for adequate anchorage and stability. 
A

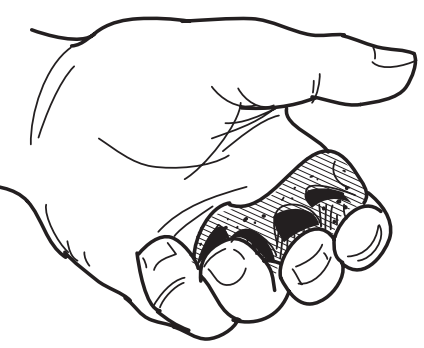

(B) Loam, a medium-textured soil. A short ribbon can be formed with moist soil. The ribbon will split readily $B$ and will break away when about $1 / 2$ inch long. A moist cast of a loam soil will bear some handling.
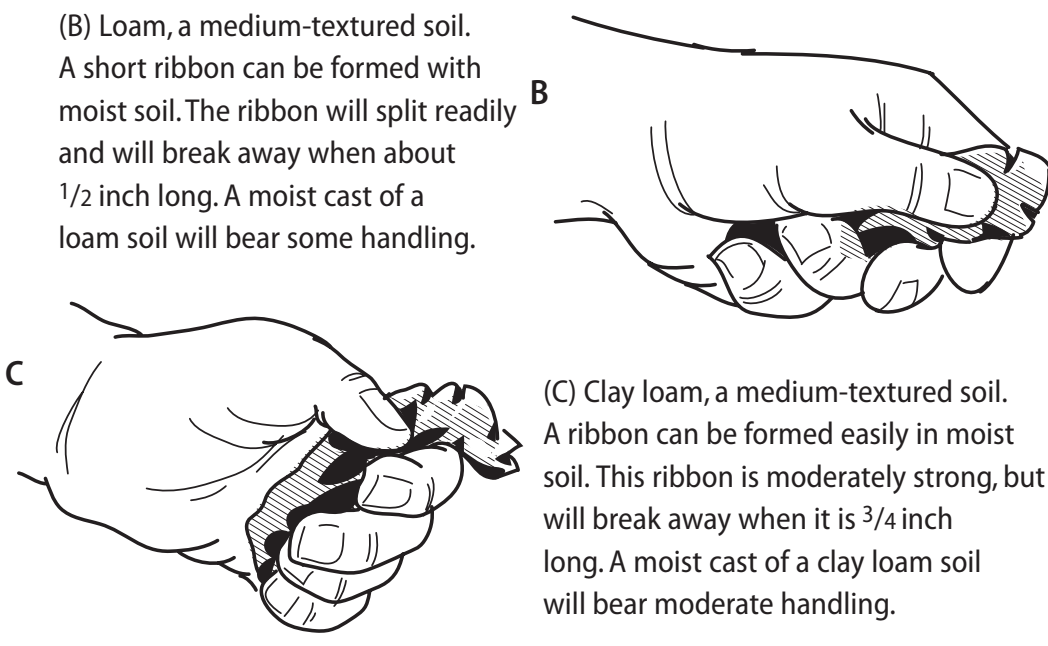

(C) Clay loam, a medium-textured soil. A ribbon can be formed easily in moist soil. This ribbon is moderately strong, but will break away when it is $3 / 4$ inch long. A moist cast of a clay loam soil will bear moderate handling.

(D) Clay, a fine-textured soil. A strong ribbon can be formed in moist soil. The ribbon often will be more than 1 inch long. A moist cast will bear considerable handling.

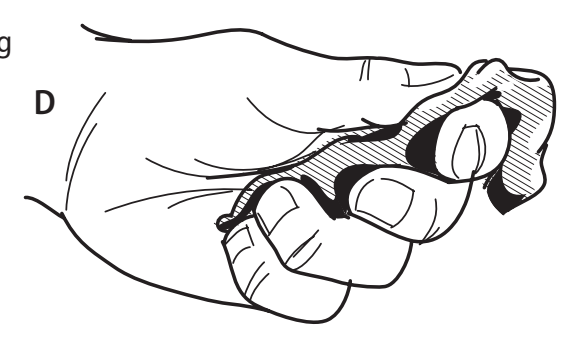

Figure 12. Determining soil texture by the feel method. Source: After Pittenger 2006, p. 79.
Layered soils often result from well-intentioned homeowners adding small amounts of compost to shallow, upper soil layers instead of mixing it evenly and deeply (several inches deep). Amending poorquality soil with compost mixed deeply and evenly (at least 3 inches deep) before planting landscape plants (other than trees) adds valuable organic matter. In turn, the water-holding capacity of sandbased soils and the drainage of clay-based soils are enhanced. This topic is covered in more detail below.

Tree roots can easily be injured and destroyed by soil compaction. Construction activities should be kept several feet from tree trunks to maintain healthy trees that are not prone to failure as they mature. Tiny root hairs absorb water and nutrients while larger roots anchor the tree and store mineral elements and carbohydrates. Roots of most trees grow horizontally two to three times the diameter of the dripline, and most live in the top 18 inches of soil, making them particularly susceptible to soil compaction.

\section{Greencycle-recycle organic matter}

You do not need to throw away or send most greenwaste (such as lawn clippings, prunings, or dead garden and landscape plants) to the landfill. Instead, reuse these valuable products in your landscape for healthier plants and a cleaner environment. Californians generate over 43 million tons of municipal solid waste each year, or 6.4 pounds per person per day. Recycling greenwaste improves soil health and diverts thousands of tons of potential soil amendments and mulch from overflowing landfills each year.

Several environmentally friendly options exist for using greenwaste that result in a healthier landscape and garden. These methods may be used singly or in combination to achieve your "zero accumulation" goal. Zero accumulation means that you reuse all the greenwaste that you generate. Options for reusing greenwaste (greencycling) include composting, mulching, grasscycling, incorporating, soil amending, and making your own potting soil. The greencycling system that is best for you largely depends on the kinds of greenwaste you produce and your specific home horticulture needs for the end products.

Mulch. Most landscape plants benefit from a layer of mulch, 


\section{BUILdINg Your OWN Compost Pile}

Step 1: Find a convenient location near a source of water in a partly sunny location.

Step 2: Collect enough "browns" (leaves, tree trimmings under 1 inch) and "greens" (grass clippings, old flowers and vegetables) to make a pile at least 1 cubic yard in volume ( 3 by 3 by 3 feet). Chop or shred coarse materials so they will break down faster. (Avoid adding large pieces of wood, which decompose slowly, and large volumes of ash from wood burning stoves, which can significantly increase pH.)

Step 3: Mix the materials regularly, and add moisture as needed. Squeeze a handful of the mixed material to check its moisture level. If you can barely squeeze out water (similar to a wrungout sponge), the moisture level is about right. The pile should be slightly moist rather than soggy or dry. If the pile is too dry, add water and check the moisture again. If it is too wet, mix in some drier material.

Step 4: Continue adding browns and greens, and mix the pile regularly. which, by definition, is material applied on top of the soil around plants rather than mixed into the soil. Mulches reduce soil evaporation and runoff, aid in weed and erosion control, buffer soil temperature, reduce compaction from foot traffic and construction, and result in more attractive plantings. In general, a 3- to 4-inch layer of mulch (once settled) is recommended and, over time, may need to be replenished. Coarse materials, such as wood chips, can be applied to a depth of 4 inches as long as soil drainage is good. Wood chip mulch is often available free or for a nominal fee from local tree-trimming services. Thick blankets of fine-textured mulch made from compost should be avoided because it can mat; reduce adequate water and air movement; and blow or wash away. Wood chip mulches can be applied on garden walkways as well as around plants. Adding a leaf mulch to a vegetable or flower garden using deciduous tree foliage in the fall is a great way to extend high soil temperatures into the winter. Remember to remove the mulch early in spring so the soil can warm up quickly if you live in an area with cool springs.

Grasscycle. Grasscycling is the easiest way to recycle lawn clippings. In grasscycling, clippings are simply left on the lawn to decompose, rather than being bagged. Besides diverting organic matter from landfills, grasscycling supplies valuable organic material and nutrients to the soil. Studies have indicated that grass clippings contain up to 3.8 percent nitrogen, 0.56 percent phosphorus, and 2.3 percent potassium (Heckman and Krogmann 2006). Grasscycling reduces mowing time, buffers soil temperature, reduces evaporation, and aids in erosion control. Contrary to popular belief, grasscycling does not contribute to thatch (a partially decomposed layer of turfgrass stems, shoots, and roots accumulating at the soil surface). Grass clippings are composed mostly of water, and they decompose rapidly when left on the lawn. However, it is necessary to mow at least weekly when grasscycling to avoid a buildup of excess clippings on your lawn. Many makes and models of dedicated mulching mowers are available on the market. Conventional bagging lawnmowers are good choices if you prefer to compost your lawn clippings instead of grasscycling. Grass clippings are a valuable source of nitrogen for your compost pile.

Maintaining your lawn at or slightly below the recommended mowing height is important when grasscycling. In general, you should mow often enough so that you never reduce the leaf height by more than one-third during any given mowing. Common bermudagrass lawns should not be mowed until blades reach 2 inches long, while tall fescue lawns can grow to 3 inches tall before mowing. Cutting your lawn at the right height is one of the most important elements of successful grasscycling and maintaining a healthy lawn.

Incorporate. Burying organic matter, such as dead plants, grass clippings, and tree and shrub prunings, along with small amounts of kitchen waste such as fruit and vegetable peels, improves soil texture and may add nutrients over time. Find a vacant patch of ground, remove a shovelful of soil at least 6 inches deep, deposit your organic matter, and replace the soil. Most waste will decompose within 1 month. Be aware that oils, meat, and dairy products do not readily break down and may attract hungry animals.

Compost. Compost is the stable, humuslike product that results from the biological decomposition of organic matter under controlled conditions called composting. Making and using compost in your 

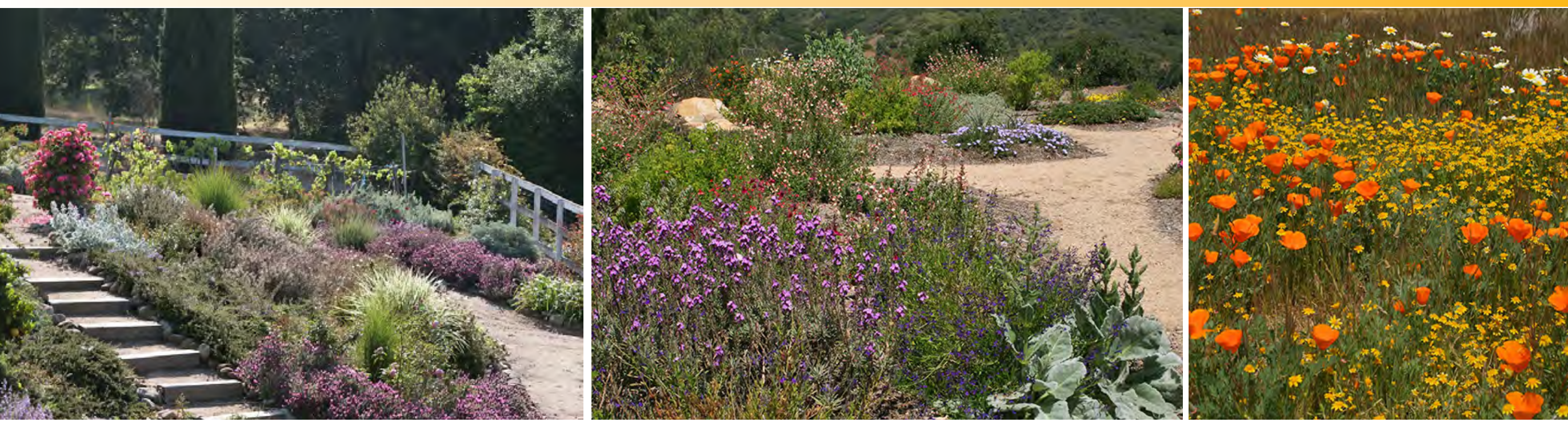

Examples of beautiful, water-efficient sustainable landscapes. Photos: Martin Fletcher, California Gardens.com.

backyard diverts organic matter from landfills and provides a valuable soil conditioner that improves urban soils. Tree and shrub prunings, lawn clippings, small chips, and vegetable scraps are all excellent starting products for making your own compost in a pile or bin.

Soil is a valuable yet limited resource that can be improved, conserved, and increased through the proper use of compost. Compost applied as a soil amendment that is mixed evenly and deeply into soil accomplishes the following:

- improves soil tilth and structure

- improves the water and nutrient-holding capacity of sandy soils

- improves drainage and aeration in heavy soils

- prevents or decreases erosion

- replenishes some nutrients required for plant growth

- increases the activity and diversity of soil microorganisms

- filters stormwater runoff

- may reduce the incidence or severity of certain soilborne diseases

Mix several inches of compost into your vegetable and flower gardens before you plant, or use it as a potting soil as is. Avoid planting trees in compost because it can result in a small root zone confined to the composted area that is unable to support a maturing tree. For a more thorough description of backyard composting, download the free UC ANR publication Compost in a Hurry (Geisel and Unruh 2007).

\section{Protect and Encourage Appropriate Wildlife}

For hundreds of thousands of years, plants, animals, and other living organisms have interacted with one another and the environment. As a result, species have adapted and changed over time, shaping an ecosystem supporting a wide variety of life forms. It is estimated that 6,000 acres of open space are lost each day in the United States, resulting in a significant reduction of wildlife habitat. In addition to losses due to urban sprawl and development, natural habitats for wildlife have been further reduced by misuse of pesticides, invasive plant species, climate change, and other stresses.

Ensuring a balanced ecosystem that supports a wide array of plant and animal species should be a primary goal of your sustainable landscape. Butterflies, birds, beneficial insects, and other wildlife will be attracted to your landscape if you provide their basic requirements. 


\section{The Basic Wildlife Needs: Food, Water, and Cover}

Food

Food supplies energy and nutrients. Wildlife species native to your area have largely evolved along with plants that are also native. An excellent way to provide food for wildlife is to replicate native plant communities in your landscape. Never feed any wildlife species human scraps, trash, or pet food. These types of foods are unhealthy for most wildlife. In addition, some species of mammals, such as raccoons, skunks, bears, and deer, can become dependent on human-provided food. Many of these animals lose their natural fear of humans, leading to potentially dangerous encounters.

Each wildlife species has its own nutritional needs, which change seasonally and across its life cycles. A diversity of fruits and berries; grains and seeds; nuts and acorns; browse plants that include twigs and buds; forage plants (grasses and legumes); and aquatic plants are recommended to attract a wide diversity of wildlife. Insects and other invertebrates that are attracted to flowers, shrubs, and trees are also a viable food source for wildlife.

Providing food in fall and winter is especially important in colder California climates. Wildlife species that are inactive or hibernate in the late fall and winter need to increase their caloric intake in the late summer and early fall in order to survive. Migratory species need a steady source of food over a wide geographic area. Monarch butterflies rely on late-blooming plants, such as aster and goldenrod, to provide the nectar they require for their journey south.

Maintaining a steady supply of predators that feed on unwanted insects and other pests is an important reason for attracting and nurturing appropriate wildlife. When predators are present, ecosystems tend to be more diverse, more resilient, and healthier. Predators maintain an ecosystem balance by keeping populations of their prey in check. Spiders are common garden predators that are voracious eaters, consuming large numbers of insects. Other predators include ladybird beetles, salamanders, and owls.

Although the best way to provide food for wildlife is to preserve and restore local plant communities, supplemental feeders are recommended when this is impractical. Birds can be safely fed with feeders. Many bird species rely on natural food sources first and use feeders only to supplement their diet as needed. They do not become dependent on feeders or delay seasonal migration or starve if you stop feeding them. Since the type of seed placed in the feeder can impact what species of birds you attract, be sure to select seeds appropriate for your habitat. While black-oil sunflower will be eaten by almost any bird species, safflower is less appealing to squirrels and to birds such as English or house sparrows.

\section{Water}

Many wildlife species require water for drinking, and many need it for bathing as well. How you provide water to encourage a healthy backyard habitat should be determined by the type of wildlife you want to attract. Options range from water gardens to simple birdbaths to puddles. If you have a water habitat on your property, preserve it. Be sure to change water regularly to prevent mosquito breeding.

Cover

Many wildlife species rely on cover, or shelter, to provide protection from the elements and predators. Some predators rely on cover as camouflage. Cover is also used for feeding, resting, nesting, mating, and rearing young. Cover comes in many different types and can be both living (e.g., trees, shrubs, grasses, and flowering plants) or nonliving (e.g., rock piles, brush piles, rock walls, cavities in trees, and birdhouses). Wildlife need a sheltered place to reproduce and raise their offspring that is safe from predators, protected from inclement weather, and free of human encroachment. Many places for cover are suitable areas where wildlife can also raise young, such as birdhouses, wildflower plantings where butterflies and moths lay eggs, and ponds for fish and amphibians.

Additional ways to encourage appropriate wildlife to your sustainable landscape

1. Limit the size of your lawn. Grass offers very little food or cover for most wildlife. 
2. Provide snags and brush piles. As trees become diseased, insect infested, or die, consider leaving them either standing or lying. (Note that this practice should be avoided in situations where disease or insect spread can occur.)

3. Plant native vegetation whenever possible. Natives provide optimum food and cover and often require less maintenance.

4. Remove invasive exotic plants. Invasive plants aggressively take over natural habitats and can outcompete native vegetation.

5. Plant a wide variety of flowering plants with varying bloom periods to ensure pollination. Make sure to include species that produce berries or seeds that provide food for wildlife.

6. Provide bird and bat houses and bird feeders. Adding different types of feeders and houses helps increase wildlife diversity.

7. Manage pets. Cats and dogs can drastically impact wildlife. Cats are excellent hunters and kill millions of birds and mammals in the United States each year.

8. Reduce pesticide use. Implement integrated pest management strategies discussed in this publication and found at the UC IPM website, http://www.ipm.ucdavis.edu/.

9. Expand the size of your habitat. The required habitat for many wildlife species is much larger than what you could provide within your yard. Consider partnering with your neighbors to create larger wildlife habitats.

\section{Conserve Energy}

Energy-efficient landscape practices include choosing plants wisely to reduce inside energy consumption while maintaining the functionality of the outdoor landscape. Incorporating recommended sustainable landscaping principles and practices that modify your outdoor environment also positively impacts your indoor environment, reducing energy and utility costs. Properly placed vegetation, use of energy-conserving landscape maintenance measures, and use of energy-efficient lighting can significantly reduce energy use while keeping your home warm in the winter and cool in the summer. Increasing the energy efficiency of your home and landscape can increase its real estate value as well as its aesthetic value.
An obvious starting point is in the area of tool selection. Consider dusting off your hand tools and retiring power tools. As mentioned earlier in this publication, using a rake or broom instead of a hose to sweep up yard waste conserves energy, keeps fertilizers and pesticides out of the waterways-and provides exercise!

What about lawn mowers? Electric mowers are more energy efficient and quieter than their gas-powered counterparts. Push mowers are another green option. If you are currently using an older-model gas mower, consider replacing it with a more efficient model or an electric or push-type mower. Newer gas mowers with small engines run much cleaner than older models.

You can significantly reduce indoor energy use by strategic placement of trees. In hot inland regions of California, well-placed trees can provide shade that cools roofs, walls, and windows. Trees can reduce surrounding air temperatures by $9^{\circ}$ to $12^{\circ} \mathrm{F}$. Since about 40 percent of the unwanted heat that builds up in your house enters through windows, it is important to prevent sunlight from entering. Because the summer sun is so high, almost twice as much solar energy enters through the east and west windows as the south windows. This is especially true if there is a roof overhang on the south side of your house.

Deciduous trees (trees that lose their leaves each winter) offer one of the best opportunities to reduce home cooling costs and energy use. Planting them on the northeast-to-southeast and northwest-to-southwest sides of your house provides excellent protection from the summer sun by shading the roof, walls, and windows. Deciduous trees permit winter sunlight to warm the house. This is why it is best to avoid planting deciduous trees on the south side of your house if you live in a cool climate. In the winter, even bare branches of mature deciduous trees can reduce the amount of sun reaching your home.

When choosing a shade tree to plant, consider its ultimate height, spread, growth rate, and shape. These factors influence the cooling benefits of the tree. For western exposures, wide-spreading trees are best. Tree species that never grow tall will not provide much shade. In general, select trees that shade as much of the roof 
and walls of your home as possible. Resist the urge to cover a small portion of your home with dense shade if, instead, a larger area could be covered with less dense shade. This will ensure optimum summer cooling. If you're concerned about preserving your view, keep the sun's path in mind and plant one or two smaller trees slightly to the side of the window.

Well-placed landscape plantings also reduce the impact of "heat islands." Air temperatures under shade trees can be $20^{\circ}$ to $25^{\circ} \mathrm{F}$ cooler than air temperatures above blacktop. Strategically planting turf and groundcovers next to driveways, streets, and sidewalks can significantly reduce the temperature of surrounding areas as well. Temperatures just a few inches above turf and groundcovers can be up to $20^{\circ} \mathrm{F}$ cooler than above black asphalt and $12^{\circ} \mathrm{F}$ degrees cooler than above lighter-colored concrete surfaces.

Landscape plants with low crowns provide excellent windbreaks by blocking wind close to the ground. Dense plantings of evergreen shrubs and small trees on the north and northwest side of your home can serve this purpose. To reduce wind chill, vertical windbreaks with approximately 50 percent density positioned at a $90^{\circ}$ angle to the direction of the wind are preferred over a dense, solid wall, which can result in turbulence.

Energy-efficient lighting for residential landscapes has gained popularity in recent years. Light-emitting diodes (LED) are both energy efficient and cost effective in the long run. For these reasons, they have quickly gained popularity in residential as well as commercial landscapes. While the initial cost of LED lamps is higher than other lighting options, their lifespan is much longer (around 200,000 hours). LED lighting is versatile and is also available in solar-powered units, although they are less effective during the winter.

Other obvious changes you can readily make to conserve energy in your home landscape are to buy locally; propagate your own plants and share them with your neighbors; use local or recycled building materials; add edibles to your sustainable landscape; and grasscycle and compost your lawn and landscape trimmings.

\section{Summary of Sustainable Landscaping Principles and Practices}

Selecting suitable landscape plants for your climate and microclimate and following best management practices (i.e., practices that are water efficient, protect ground and surface water quality, nurture the soil, recycle organic matter, protect and encourage appropriate wildlife, and are energy efficient) can greatly enhance the beauty of your landscape and protect the environment for future generations. In addition to recommendations in this publication, UC ANR has a wide array of information covering many of these topics in extensive detail. The UC ANR website, http://anrcatalog.ucanr.edu/, and the UC IPM website, http://www.ipm.ucdavis.edu, are great places to start. Many publications are free and instantly downloadable, while others carry a nominal charge.

\section{References}

Brenzel, K. N., ed. 2012. The new Sunset western garden book: The ultimate gardening guide. 9th ed. Menlo Park, CA: Sunset.

California Department of Housing and Community Development (HCD). HCD website, http://www.hcd.ca.gov/codes/shl/Preface ET_Emergency_Graywater.pdf.

Dreistadt, S. 2004. Pests of landscape trees and shrubs. Oakland: University of California Agriculture and Natural Resources Publication 3359.

Geisel, P. M., and C. L. Unruh. 2007. Compost in a hurry. Oakland: University of California Agriculture and Natural Resources Publication 8037. Available at the UC ANR website, http://anrcatalog.ucanr.edu/Details.aspx?itemNo=8037.

Harivandi, M. A., J. Baird, J. Hartin, M. Henry, and D. Shaw. 2009. Managing turfgrasses during drought. Oakland: University of California Agriculture and Natural Resources Publication 8395. Available at the UC ANR website, http://anrcatalog.ucanr.edu/ Details.aspx?itemNo $=8395$.

Hartin, J., P. M. Geisel, and C. L. Unruh. 2001. Lawn watering guide for California. Oakland: University of California Agriculture and Natural Resources Publication 8044. Available at the UC ANR website, http://anrcatalog.ucanr.edu/ IntegratedPestManagement/8044.aspx. 
Heckman, J. R., and U. Krogmann. 2006. Nutrient management of land applied grass clippings. Rutgers Cooperative Extension Publication FS1023. New Jersey Agricultural Experiment Station (NJAES) website, http://njaes.rutgers.edu/pubs/publication.asp?pid=FS1023.

Pittenger, D. R., ed. 2006. Retail garden center manual. Oakland: University of California Agriculture and Natural Resources Publication 3492.

Reynolds, C. A., M. L. Flint, et al. 2004. UC guide to healthy lawns. Oakland: University of California Agriculture and Natural Resources Publication. Available at the UC IPM website, http://ipm.ucdavis.edu/TOOLS/TURF/.

Schwankl, L., and T. Prichard. 1999. Drip irrigation in the home landscape. Oakland: University of California Agriculture and Natural Resources Publication 21579.

Stapleton, J. J., C. A. Wilen, and R. H. Molinar. 2008. Pest notes: Soil solarization for gardens \& landscapes. Oakland: University of California Agriculture and Natural Resources Publication 74145. Available at the UC ANR website, http://ucanr.edu/sites/ Solarization/files/114635.pdf.

\section{AcKnOWLedgments}

Special thanks to UCCE Lake County Laboratory Assistant Carolyn Shaffer and to UCCE Orange County Master Gardener Coordinator Sharon Stolen for their dedication to sustainable landscaping practices and principles and their valuable contributions to this publication.

Gratitude is also extended to Mary Louise Flint, Associate Director for Urban and Community IPM, UC Statewide IPM Program, and UC Cooperative Extension Entomologist, for her valuable suggestions.

\section{Measurement Conversion Table}

\begin{tabular}{|l|c|c|l|}
\hline U.S. customary & $\begin{array}{c}\text { Conversion factor } \\
\text { for U.S. customary } \\
\text { to metric }\end{array}$ & $\begin{array}{c}\text { Conversion factor } \\
\text { for metric to U.S. } \\
\text { customary }\end{array}$ & Metric \\
\hline inch (in) & 2.54 & 0.394 & centimeter (cm) \\
\hline foot (ft) & 0.3048 & 3.28 & meter (m) \\
\hline cubic yard (yd $\left.{ }^{3}\right)$ & 0.765 & 1.307 & cubic meter $\left(\mathrm{m}^{3}\right)$ \\
\hline gallon (gal) & 3.785 & 0.26 & liter (I) \\
\hline
\end{tabular}

\section{FOR MORE INFORMATION}

To order or obtain ANR publications and other products, visit the ANR Communication Services online catalog at http://anrcatalog.ucanr.edu or phone 1-800-994-8849. You can also place orders by mail or FAX, or request a printed catalog of our products from

University of California

Agriculture and Natural Resources

Communication Services

1301 S. 46th Street

Building 478 - MC 3580

Richmond, CA 94804-4600

Telephone 1-800-994-8849

510-665-2195

FAX 510-665-3427

E-mail: anrcatalog@ucanr.edu

(ㅇ) 2014 The Regents of the University of California

Agriculture and Natural Resources

All rights reserved.

Publication 8504

ISBN-13: 978-1-60107-859-9

The University of California Division of Agriculture \& Natural Resources (ANR) prohibits discrimination against or harassment of any person participating in any of ANR's programs or activities on the basis of race, color, national origin, religion, sex, gender identity, pregnancy (which includes pregnancy, childbirth, and medical conditions related to pregnancy or childbirth), physical or mental disability, medical condition (cancer-related or genetic characteristics), genetic information (including family medical history), ancestry, marital status, age, sexual orientation, citizenship, or service in the uniformed services (as defined by the Uniformed Services Employment and Reemployment Rights Act of 1994: service in the uniformed services includes membership, application for membership, performance of service, application for service, or obligation for service in the uniformed services) or any person in any of its programs or activities.

University policy also prohibits retaliation against any employee or person participating in any of ANR's programs or activities for bringing a complaint of discrimination or harassment pursuant to this policy. This policy is intended to be consistent with the provisions of applicable State and Federal laws.

Inquiries regarding the University's equal employment opportunity policies may be directed to Linda Marie Manton, Affirmative Action Contact, University of California Division of Agriculture and Natural Resources, 2801 Second Street, Davis, CA, 95618-7774, 530-750-1318. For information about ordering this publication, telephone 1-800-994-8849.

To simplify information, trade names of products have been used. No endorsement of named or illustrated products is intended, nor is criticism implied of similar products that are not mentioned or illustrated.

An electronic copy of this publication can be found at the ANR Communication Services catalog website, http://anrcatalog.ucanr.edu/.

UC This publication has been anonymously peer reviewed for technical accuracy by

PEER University of California scientists and other qualified professionals. This review process was managed by ANR Associate Editor for Urban Pest Management, Mary Louise Flint.

web-3/14-LR/CR 